\title{
Incentives and challenges for local institutions in coffee forest management: The case of Bilo-Nopha Woreda, Ethiopia
}

\author{
BEKALU DIBABA, ABEJE BERHANU \\ Department of Sociology, College of Social Science, Addis Ababa University. Addis Ababa, Ethiopia. •email: abejeye2010@gmail.com
}

Manuscript received: 18 March 2018. Revision accepted: 27 May 2018.

\begin{abstract}
Dibaba B, Berhanu A. 2018. Incentives and challenges for local institutions in coffee forest management: the case of BiloNopha Woreda, Ethiopia. Asian J For 1: 31-46. Because woodland biodiversity is threatened by various anthropogenic factors, the role of institutions in administrating natural provenances in general and woodland origins in specific increases over time. Therefore, this is the right time to find out the role of institutions in administrating natural provenances. An assessment of the role of local institutions in the management of coffee forestry, by taking the case of Bilo-Nopha Woreda, Illu Abba Bora zone as its object, became the main objective of this study. This study attempts to describe the utilization of regulation attributes, community attributes, and attributes of woodland provenances influencing the management of coffee forests in this study region, using the institutional analysis and development framework (IAD) adopted from Ostrom (2006). This study uses qualitative and quantitative research methods in the form of triangulation. From 16 Kebeles in the study region, the researchers purposively selected 3 Kebeles adjacent to the plantation woodland region. 125 households were selected from three Kebeles for quantitative interviews using a systematic random sampling technique. In addition to conducting in-depth interviews, key informant interviews and FGDs were conducted to support and strengthen data obtained through household surveys. The results reveal that both official and informal institutions manage coffee forests locally. Rules established by the government to secure coffee woodland areas decrease woodland utilization by local communities and make their ownership rights unsafe. This, in turn, will negatively affect their participation in coffee woodland management activities. Community contributions and forest provenances also influence management activities both positively and negatively. Some operate as incentives that increase management activities, including compactness, homogeneity, topography, and goods and services derived from forests; in contrast, others work as disincentives for management activities, including group size, distance, and inadequacy of clear boundaries. In addition to the challenges of administrating coffee forests, lack of ownership, illegal encroachment, and inadequate coordination between various stakeholders are the main difficulties that must be resolved to preserve coffee forests in the study region.
\end{abstract}

Keywords: Challenges, coffee, Ethiopia, incentives, local institutions

\section{INTRODUCTION}

The breadth, fluidity, and power of institutions make them hard to comprehend. Some scholars utilize the term institution to allude to an organization, such as the USA congress, a business firm, or a political party. On the other hand, other scholars utilize the term to allude to the regulations, norms, and strategies adopted by individuals operating within and across the organizations (Ostrom 1999). According to Yeraswork (1997) institution is any social adjustment initiated and managed by social regulations. Social regulation systems are shared and socially established regulation regimes determining a greater or lesser extent of who may or should participate, and who is excluded, and who should do what, when, and how about whom. Stellmacher and Mollinga (2009) said that beyond modeling human-human interactions, institutions could have a substantial role in modeling human-nature relationships. In this sense, institutions indicate a severe role in the relations between humans and woodlands as they can specify and manage human access to woodland provenances.

The conventional method of natural provenance management has tended to either ignore altogether or give peripheral attention to the significant role the institutions have come to play. However, empirical evidence shows that institutions form a fundamental link between people and their environments. Through these institutions, individual and collective actions associated with access to, control over, and the utilization of natural provenances are arranged (Teklu 2006).

Zewdie (2009) argued that natural provenance management is often formed by several overlapping institutions, i.e., official and informal from the social, political, economic, and cultural spheres. The official institutions operate at the local, regional, and national levels to administrate the woodland and woodland provenances; in contrast, informal/autochthonous institution of the community works at the local level to manage natural provenance in general and woodland origin in specific. Teklu (2006) also added the particular significance of locallevel institutions in securing and administrating natural provenances. There is a sprouting acknowledgment of locallevel institutions' importance and centrality when exploring and developing genuine provenance preservation and utilizing concepts.

In Ethiopia, both informal/customary institutions and official/state-triggered institutions participate in coffee woodland provenances management activities at the local level. Informal/customary institutions take precedence in 
the management of natural provenance, while the involvement of official institutions in genuine provenance management, mainly woodland provenance, are recent phenomena (Zewdie 2009).

Distinctive studies signified that forests and woodlandderived natural provenances are not well administrated in Ethiopia, and their existence keeps on being endangered; Coffee woodland and the genetic origins of the wild coffee and the associated flora and fauna are vanishing rapidly due to the denudation of the ecosystems, especially in the past few decades. The underlying causes of the denudation are social, economic, political, and institutional (Tadesse and Demel 2001; Woods et al. 2012; Amogne 2013). In support of this idea, Mellese and Mohammud (2005) signified that, in Ethiopia, because of the less coordination among several institutions; poor institutional adjustments; deficiency of the necessary trained human resources, especially at the grassroots levels; lack of political commitment on the side of officials; inadequacy of the culture of listening to expert opinions before political authorities decide decisions; mismanagement; overemphasis on fast economic growth at the expense of the environment (through investment projects), among others, the country is suffering from terrible environmental decline.

As signified above, the role played by neighborhood institutions in the management of natural provenance in general and coffee woodland in specific is high. Therefore, having the explanations mentioned above in mind, the researcher wished to perform a study on assessing the role of local-level institutions in coffee woodland management activities in the case of Bilo-Nopha Woreda, Iluu Abba Bora Zone.

The objective of this research was: (i) To investigate the effectiveness of regulations in utilization to administrate coffee woodland in the study region. (ii) To examine the impact of local woodland user attributes in the management of coffee woodland. (iii) To identify the attributes of woodland provenances that influence the management of coffee woodland. (iv) To investigate the primary challenges of coffee woodland management.

\section{MATERIALS AND METHODS}

\section{Description of the study region \\ Geographical setting}

Iluu Abba Bora is located in the southwestern part of Oromia Regional State, Ethiopia. It is bounded by East Wellega and Jimma zones in the east. Iluu Abba Bora also shares a border with West and East Wellega in the North, SNNPR in the south, and Gambella Regional State in the west. The entire region of the zone is 1,633156.6 ha and is divided into twenty-two districts (Zewdie 2009).

Bilo-Nopha Woreda is found in Iluu Abba Bora zone of Oromia Regional State at about $615 \mathrm{~km}$ from Addis Ababa, the capital of Ethiopia, and $18 \mathrm{~km}$ from Mettu, which is the Administrated seat of Iluu Abba Bora zone. The whole land region of the Woreda is 39,000 ha, and the woreda comprises 16 kebele.

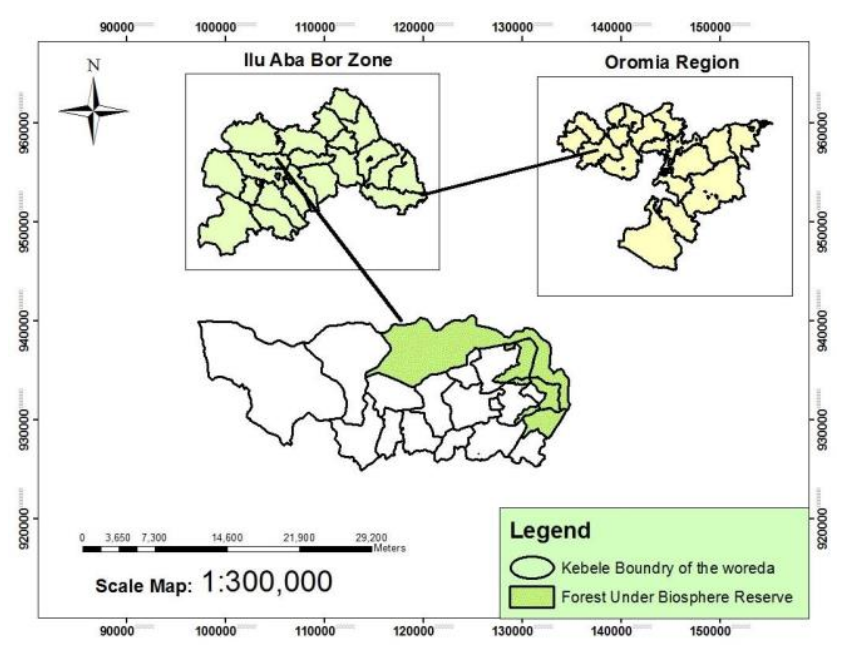

Figure 3. Map of the study region

\section{Climate}

Bilo-Nopha Woreda is situated between $8^{\circ} 2^{\circ} 42^{\circ \circ} \mathrm{N}$ and $8^{\circ} 31^{\circ} 18^{\prime}$, North and $35^{\circ} 37^{\circ} 48^{\circ} \mathrm{E}$ and $36^{\circ} 05^{\circ} 18^{\circ}$ East. The agro-ecological region of the Woreda is $95 \%$ below highland (badda), and the remaining 5\% is lowland (Gammoojji). The mean annual temperature of the Woreda is $18-23^{\circ} \mathrm{C}$, and the mean annual rainfall is from $1200-2100$ $\mathrm{mm}$ per year. It is a unimodal type of rainfall that escalates from May to October and reduces in December. Concerning the topographic location, most parts of the Woreda are Mountains, and rift valleys cover some parts of the region. Bilo- Nopha Woreda is located 1700 meters above sea level.

\section{Population and economic condition}

According to the Woreda Administrative Report of (2013), the total population of Bilo-Nopha Woreda population is 30,383 from this the number of males are 16,001 , and females are 14,382 . Out of the total population in the Woreda, only 3,750 people live in the town region, and the rest 26,633 live in the country regions.

Concerning the ethnic composition, most of the respondents of the residents belong to Oromo ethnic groups. Other ethnic groups from Amara and Tigray also exist in the Woreda due to resettlement and in-migration in the preceding few decades. In the study region, distinct religious organizations are also lived; Orthodox, Protestants, and Muslims are dominant.

Most of the neighborhood society's economic activities are involved in agriculture and agriculture-related activities. Woodland provided goods and service like coffee, honey, timber extraction, etc. which are the primary agricultural activities of the community and accounts up to $75 \%$ of local subsistence strategies, on the other hand, crop production like maize, sorghum, and teff) and livestock increase like cattle, sheep, goats, donkeys, etc., accounts for $20 \%$ of the subsistence strategy of the community. Few urban dwellers account for $5 \%$ being involved in distinct small trade and daily labor activities. 


\section{Natural provenance endowment}

South-western Ethiopia in general and Illu Abba Bora zone in specific is famous for their natural provenance endowments. Bilo-Nopha Woreda is one of the vast woodland regions that consist of many species, and it was incorporated into Yayo woodland priority areas (NFPA) for preservation in 1999. The whole land region of the Woreda is 39,000 ha, which is covered by distinct kinds of land uses. According to secondary data of Woreda land management, coffee woodland cover 20,230 ha of total land regions; on the other hand, Savannah woodland, grazing land, savannah, and marshland covered 9,063 ha of entire land regions. The cultivation register on rounds the remaining 9,707 ha of the land surface.

The woodland ecosystem is endowed with a variety of plant species. The most prevalent are Hambabessa (Albizia gummifera), Waddessa (Cordia africana), Qararoo (Aningeria adolfi-friederici), Hogda (Ficus vasta), Sondi (Acacia lahai), Alale (Albizia grandibracteata), and others with their unknown scientific names like Bakkannissa, Lookoo, Abrangoo-Jaldessaa, Qassoo, and Lolchiissa are some of the plant species that existed in the coffee woodland regions.

According to secondary data from the Woreda agriculture and woodland preservation office, the coffee woodland of Bilo-Nopha Woreda has distinct species of animals. Anubus baboon (jaldessaa), colobus monkey (weenni), and more than fifteen (15) other species of animals can be found in the coffee woodland region.

\section{History of Bilo-Nopha forest conservation}

During the imperial period, Bilo-Nopha Woreda coffee woodland region was held as prevalent property provenance and private goods of the neighborhood society. The current core zone region of the woodland was under the landlord's Conthe Troll, and the buffer zone region of the woodland was owned as private goods of local communities through Gabbar system. After nationalizing land during the military regime, a distinct peasant association and committee controlled the coffee woodland region. The association and individual private property with full utilization rights influenced the coffee woodland region. After EPRDF came to power in 1991, the coffee woodland region became under the de jure ownership of the governments to maintain distinct biodiversity in the coffee woodland regions.

The forestry management at the federal level has classified 58 most important high woodland regions in Ethiopia as National Forest Priority Areas since 1985 (Zewdie 2009). From the 58 National Forest Priority Areas in the country, the Illubabor zone has five National Forest Priority Areas. Yayu Forest, Gaba-Dhidhesa, Gabre-Dima, Sibo-toti Qobo, and Sale-Nono.

Due to its national and international significance, the Bilo-Nopha coffee woodland region has been designated as a site for wild Arabica coffee (Coffea arabica) preservation as a gene reserve by the government of Ethiopia since 1999; under the control of Yayo National Woodland priority regions which consists other five Woreda's that woodland region were adjacent, these including Yayo, Chora, Alge, Hrumu and Dorani. The coffee woodland region covers 13,305 ha of land from four adjacent kebeles, including (Ulmaya, Kitabir, Suli, and government woodland that bounded to those kebeles). After restricting the woodland region as a national woodland priority region for biodiversity preservation, coffees' woodland utilization and management activities are limited and strictly forbidden.

\section{Research design}

This study employed cross-sectional and approximating longitudinal research designs to gain data on the subject under investigation. To get information regarding the regulation in utilization to manage the coffee woodland region, the behavior of woodland user group, attribute of woodland land and its derived provenances and challenges of coffee woodland management, cross-sectional research design the most appropriate one.

An approximate longitudinal research design was also employed to get information regarding the participation level of neighborhood society in the management activities of coffee woodland before restriction and their past ownership right in the secured woodland regions.

\section{Research method}

Triangulation is primarily a way of assuring the legality of research results by utilizing distinct research methods and approaches. Besides, it has also added the benefit of authorizing the researcher to cover different aspects of their research goals or inquiry by utilizing different provenances, data, and research methods (Yeraswork 2010). Therefore, in this study, methodological triangulation was used to address the distinct goals of the study. Additionally, it is also utilized to sustain and verify quantitative data with qualitative one.

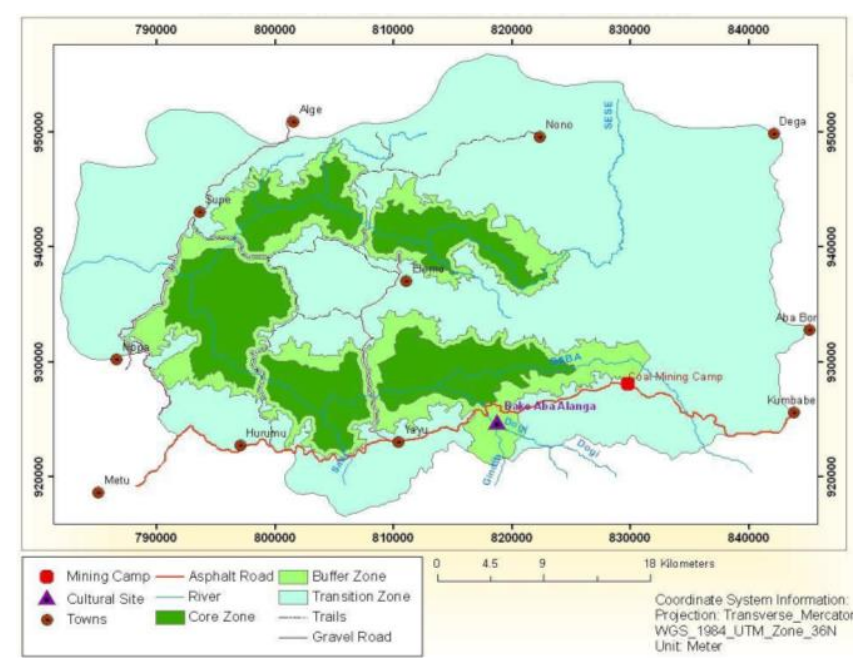

Figure. The proposed biosphere reserve map. Source: Adapted from Andnet (2010) 


\section{Methodological triangulation}

The researcher has utilized a methodological triangulation to verify the research result briefly in the following Table 1 .

\section{Study population}

The target population of this study was households of three selected kebeles who live in coffee woodland adjacent to Bilo-Nopha Woreda, including Ulmaya, Kitabir, and Suli.

\section{Sample design and sample size determination}

Many reasons make sampling more beneficial rather than complete enumeration. These include considerations regarding time, cost and available provenances, and practicability (Yeraswork 2010). Both probability and nonprobability sampling techniques have been utilized to draw the required number of sample units for this study. Accordingly, kebeles were selected purposively from the entire kebele in Bilo-Nopa Woreda; therefore, the researcher purposively selected 16 kebele adjacent to the Woreda coffee woodland regions (bio-sphere reserve regions). And then, household heads for information have been chosen from the three kebeles using a systematic sampling method.

Purposive sampling was also employed to select the required number of in-depth interviews, key informants, and FGD discussants. Respondents for information were purposively selected based on their knowledge and experience, including (members of neighborhood society, well-known neighborhood society elders, and experts at a distinct level) on the subject under investigation.

This study has been conducted in the three selected sites of Bilo-Nopha Woreda, directly contacting the coffee woodland regions. The researcher utilized the following formulas for sample size determination from the total number of households in the three selected kebeles.

$\mathrm{S}=\mathrm{X}^{2} \mathrm{~N} \mathrm{P}(1-\mathrm{P}) \div \mathrm{d}^{2}(\mathrm{~N}-1)+\mathrm{X}^{2} \mathrm{P}(1-\mathrm{P})$

$\mathrm{S}=$ required sample size.

$\mathrm{X}^{2}=$ the table value of chi-square for 1 degree of freedom at the desired confidence level (3.841).

$\mathrm{N}=$ the population size.
$\mathrm{P}=$ the population variability (assumed to be 0.10 since the population is homogeneous in terms of geography, similar social class, and similar economic activity).

$\mathrm{D}=$ the degree of accuracy expressed as a proportion $(0.5)$. The total number of households of the three selected kebele $(\mathrm{N})$ is 1142 .

The total households of Ulmaya Kebele $\left(\mathrm{N}_{1}\right)=453$, The total households of Kitabir Kebele $(\mathrm{N} 2)=261$, and The total households of Suli Kebele $($ N3) $=428$.

$\mathrm{S}($ Total number of the sample $)=$ ?

$\mathrm{X}^{2}=$ at $95 \%$ level of confidence is 3.841 ,

$\mathrm{d}=5 \%$ or 0.05 and $\mathrm{P}=0.1$

Therefore, using the above formula,

$$
\begin{aligned}
& S=\frac{(3.841)(1142)(0.1)(0.9)}{0.05{ }^{2}(1142-1)+(3.841)(0.1)(0.9)}=125 \text { (Approximate) } \\
& \text { sample of respondents will be used for this study. }
\end{aligned}
$$

On the other hand, to determine the proportion number of sample (respondents) in Ulmaya Kebele (n1), Kitabir Kebele (n2) and Suli Kebele (n3), the researcher used the following formula.

$$
\begin{aligned}
& \mathrm{n}_{1}=\mathrm{S}\left(\mathrm{N}_{1} / \mathrm{N}\right) \text { and hence } \mathrm{n}_{1}=125(453 / 1142)=50 \\
& \mathrm{n}_{2}=\mathrm{S}\left(\mathrm{N}_{2} / \mathrm{N}\right) \text { and hence } \mathrm{n}_{2}=125(261 / 1142)=28 \\
& \mathrm{n}_{3}=\mathrm{S}\left(\mathrm{N}_{3} / \mathrm{N}\right), \text { which is } \mathrm{n}_{3}=125(428 / 1142)=47
\end{aligned}
$$

Hence, from Ulmaya Kebele, 50 respondents, Kitabir Kebele, 28 respondents, and Suli Kebele, 47 respondents have been picked out proportionally (Table 2). Systematic sampling was utilized in this study to allocate questionnaires. The interval is gained by dividing the specified sample population (as determined by the sample size formula) for the total population multiplied by a

\begin{tabular}{|c|c|c|c|}
\hline Objective & Units of analysis & Data sources & $\begin{array}{l}\text { Methods of data } \\
\text { collection }\end{array}$ \\
\hline $\begin{array}{l}\text { The effectiveness of } \\
\text { regulation in utilization to } \\
\text { manage the coffee forest in } \\
\text { the study regions. }\end{array}$ & $\begin{array}{l}\text { Forest user community Woreda } \\
\text { management, agricultural and } \\
\text { forest office, district manager of } \\
\text { biosphere region }\end{array}$ & $\begin{array}{ll}\text { A. } & \text { Sample of household heads, } \\
\text { B. Key informants } \\
\text { C. In-depth interviewee } \\
\text { D. Forest user community as a group }\end{array}$ & $\begin{array}{l}\text { Household survey } \\
\text { In-depth interview } \\
\text { FGD }\end{array}$ \\
\hline $\begin{array}{l}\text { Attribute to neighborhood } \\
\text { society }\end{array}$ & Forest user community & $\begin{array}{l}\text { A. Sample of household heads, } \\
\text { B. In-depth interviewee } \\
\text { C. Forest user community as a group }\end{array}$ & $\begin{array}{l}\text { Household survey } \\
\text { In-depth interview } \\
\text { FGD }\end{array}$ \\
\hline $\begin{array}{l}\text { Attribute natural } \\
\text { provenance }\end{array}$ & $\begin{array}{l}\text { Forest user community district } \\
\text { manager of biosphere region }\end{array}$ & $\begin{array}{l}\text { A. Sample of household heads } \\
\text { B. Key informants } \\
\text { C. In-depth interviewee } \\
\text { D. Forest user community as a group }\end{array}$ & $\begin{array}{l}\text { Household survey } \\
\text { In-depth interview } \\
\text { FGD }\end{array}$ \\
\hline $\begin{array}{l}\text { Challenges of coffee forest } \\
\text { management practice }\end{array}$ & $\begin{array}{l}\text { Forest user community, Woreda } \\
\text { management }\end{array}$ & $\begin{array}{l}\text { A. Forest user community as a group } \\
\text { B. Key informants } \\
\text { C. In-depth interviewee }\end{array}$ & $\begin{array}{l}\text { FGD } \\
\text { In-depth interview }\end{array}$ \\
\hline
\end{tabular}
hundred percent.

Table 2. Sample size calculations

\begin{tabular}{lcc}
\hline Kebele's & Total household & Sample population \\
\hline Ulmaya Kebele & 453 & 50 \\
Kitabir Kebele & 261 & 28 \\
Suli Kebele & 428 & 47 \\
Total & 1142 & 125 \\
\hline
\end{tabular}

Table 1. Methodological triangulation 
$\mathrm{K}=\mathrm{n} / \mathrm{N} \times 100 \%$

$\mathrm{K}=125 / 1142 \times 100 \%=11$. Thus, using the Kebele register, every $11^{\text {th }}$ was taken until 125 samples were picked.

\section{Method of data collection}

This study has utilized a methodological triangulation so as to substantiate the primary and secondary data collected from distinct provenances to achieve the stated objectives. To do so, both primary and secondary provenances have been employed. The sub-sections that follow describe the detail of primary and secondary data provenances.

\section{Primary data collection \\ Household survey}

The household survey was utilized to gain information regarding the socio-demographic characteristics, regulations in utilization to rule woodland provenance, attributes of the woodland provenance user groups, and woodland provenances regions. The survey instrument (questionnaire) consists of four parts; the first part asks respondents' demographic and socio-economic conditions. The second and third parts of the questionnaire asked about the attribute of the woodland utilization community and natural provenance and their significance in the management of coffee woodland. The fourth part of the questionnaire was about regulations that rule the woodland and their association with coffee woodland management. The final details of the questionnaire were prepared to ask about the participation of the neighborhood society in coffee woodland management.
The survey instrument was administered by translating it into the local language (Oromiffa). The researcher and enumerators undertook face-to-face interviews with the respondents since most could not read and write.

\section{Conceptualization}

Local institutions: refers to both official and informal/autochthonous institutions having a crucial role in the management of coffee woodland (Agrawal 2007)

Coffee woodland: is characterized by a high abundance of wild Arabica coffee populations and continuous, various vegetation structures (Andinet 2010).

Bio-sphere reserve region: secured woodland for sustainable preservation of biodiversity

Core zone: refers to the place exclusively established for biodiversity preservation or to ensure that all plants and animals' species and communities survive throughout the region (Zewdie 2009).

Buffer zone: refers to the region set aside as buffer the core zone from human interference while allowing preservation and sustainable utilization of woodland provenances (Zewdie 2009).

Participation: refers to the involvement of neighborhood society in coffee woodland management activities

Incentives: refers to any inducements that can enhance the management of coffee woodland

Disincentives: refers to any barriers that impede the management of coffee woodland

\section{Operationalization}

Operationalization can be seen in Table 3.

Table 3. Conceptualization

\begin{tabular}{|c|c|c|c|}
\hline Concept & Variable & Indicator & Measurement \\
\hline \multirow[t]{4}{*}{ Socio-economic status } & \multirow[t]{2}{*}{ Income } & \multirow[t]{2}{*}{ Average total income per annual } & Scale \\
\hline & & & Actual total income per year in Birr \\
\hline & \multirow{2}{*}{$\begin{array}{l}\text { Educational } \\
\text { qualification }\end{array}$} & \multirow[t]{2}{*}{ Level of education attained } & Ordinal \\
\hline & & & $\begin{array}{l}\text { Can't read and write, can read and write, } \\
\text { primary education, secondary education, } \\
\text { college and above }\end{array}$ \\
\hline \multirow{6}{*}{$\begin{array}{l}\text { Socio-demographic } \\
\text { characteristics }\end{array}$} & \multirow[t]{2}{*}{ Sex } & \multirow[t]{2}{*}{ Indicate male or female } & Nominal \\
\hline & & & Male or female \\
\hline & \multirow[t]{2}{*}{ Age } & \multirow{2}{*}{$\begin{array}{l}\text { Length of time (year) that one has been } \\
\text { alive }\end{array}$} & Scale \\
\hline & & & Age in completed year \\
\hline & \multirow{2}{*}{$\begin{array}{l}\text { Demarcation } \\
\text { regulation }\end{array}$} & \multirow{2}{*}{$\begin{array}{l}\text { The current regulation that rules coffee } \\
\text { woodland regions }\end{array}$} & Ordinal \\
\hline & & & Completely fair, fair, not fair \\
\hline \multirow{3}{*}{$\begin{array}{l}\text { Attribute of regulation in } \\
\text { utilization }\end{array}$} & \multirow{2}{*}{$\begin{array}{l}\text { Collective decision } \\
\text { making }\end{array}$} & \multirow{2}{*}{$\begin{array}{l}\text { Participation of neighborhood society in } \\
\text { collective decision making of regulation } \\
\text { design and enforcement process }\end{array}$} & Nominal \\
\hline & & & Yes, no \\
\hline & Ownership right & $\begin{array}{l}\text { Use and management rights of } \\
\text { coffee woodland provenances }\end{array}$ & $\begin{array}{l}\text { Nominal } \\
\text { Secure, insecure }\end{array}$ \\
\hline \multirow[t]{3}{*}{$\begin{array}{l}\text { Attribute of natural } \\
\text { provenances }\end{array}$} & $\begin{array}{l}\text { Distance from } \\
\text { woodland }\end{array}$ & $\begin{array}{l}\text { Actual distance of respondent's house from } \\
\text { the woodland land in hrs. }\end{array}$ & $\begin{array}{l}\text { Ordinal Less than } 30 \mathrm{~min}, 30 \mathrm{~min}-1 \mathrm{hr} \text {, } \\
1 \mathrm{hr}-1: 30 \mathrm{hr} \\
1: 30 \mathrm{hr}-2: 00 \mathrm{hr} \text { above } 2: 00 \mathrm{hr}\end{array}$ \\
\hline & \multirow{2}{*}{ Multiple utilization } & \multirow{2}{*}{$\begin{array}{l}\text { the significance of coffee woodland } \\
\text { based on the various goods and services } \\
\text { they provide }\end{array}$} & Nominal \\
\hline & & & Yes, no \\
\hline \multirow[t]{2}{*}{ Attribute to the community } & \multirow[t]{2}{*}{ Heterogeneity } & \multirow{2}{*}{$\begin{array}{l}\text { Impact of community difference in terms } \\
\text { of occupation and ethnicity to manage } \\
\text { coffee woodland }\end{array}$} & Nominal \\
\hline & & & Yes, no \\
\hline
\end{tabular}




\section{In-depth and critical informant interview}

The researcher employed semi-structured interviews to supplement the ideas and questions designed in the household survey. Informants for in-depth interviews have been selected purposively based on their knowledge and experience on the subject under study. Therefore, six indepth interviews were conducted to gather detailed information regarding local institutions' role in coffee woodland management in the study regions from neighborhood society members. To get more information about the topic under study, the researcher conducted key informant interviews with two well-known and influential Local community elders and three experts like Woreda administrator, director of agricultural and woodland preservation office, and district manager of bio-sphere reserve region.

\section{Focus group discussion}

Focus group discussion has also been utilized to triangulate the reliability and legality of the data collected by other methods. The main reason for using the focus group discussion is to understand the respondents' attitudes, feelings, beliefs, experiences, and reactions (Camic and Yardley 2003).

This study held three focus group discussions with households in the three selected kebeles. Each focus group discussion contained ten members of discussants. The member of the Focus group discussion is a neighborhood society that takes part in different social group activities, including men, women, and elders. They categorized based on their homogeneity to make them feel their ideas without frustration.

\section{Archival analysis}

The researcher reviewed several written documents, including journals, articles, books, and other documents that focus on the institution of coffee woodland management. The review of these documents helped identify the gaps in previous research on the subject under study and select appropriate research framework and tools for the analysis.

\section{Method of data analysis}

Quantitative data analysis

The quantitative data for the study were analyzed using descriptive statistics aided by the SPSS version. The findings, in turn, were analyzed qualitatively. Descriptive analysis of the data was carried-out using percentages and frequency.

\section{Qualitative data analysis}

Qualitative data collected through critical informant interviews and focus group discussions were analyzed according to the main themes of interviews and discussions. Here, qualitative data collected concerning challenges of coffee woodland management were analyzed separately as it is a different specific objective of the study. At the same time, additional data generated through interviews and FGDs concerning regulations in utilization, attributes of the community, and woodland provenance were simultaneously analyzed with survey data.

\section{Ethical consideration}

Yeraswork (2010) has clearly pointed out that "research must be managed by ethical norms and values", the researcher has been directed by the following obligatory ethical guidelines while collecting data from the sample of survey respondents and in-depth interviewees. (i) All information was collected from respondents and critical informants with their consent and willingness. (ii) All information obtained from the provenances was kept and treated confidentially. (iii) The data were analyzed and interpreted without naming any respondents or informants. (iv) Limitations and failures of the study were honestly explained. (v) The different assumptions and theories that were utilized from other provenances (books, journals, and research reports) were adequately cited and acknowledged.

\section{RESULTS AND DISCUSSION}

\section{The socio-economic and demographic characteristics of the respondents}

Socio-demographic characteristics of the respondents

The total numbers of informants were 125 individuals. The number of household heads who took part in study 118 (94.4\%) was males, and the remaining 7 (5.6\%) were females. Concerning the age categories, 47 (37.6\%) respondents fell within the age group of 41-50, and the second larger age category, $33(26.4 \%)$ respondents, fell under 21-30. The remaining $16.8 \%, 15.2 \%$, and $4 \%$ fall under the age group of 31-40, 51-60, and above 60, respectively. Regarding religious affiliation, $45.4 \%$ of respondents were followers of Protestant Christianity; the remaining $32 \%$ and $22.6 \%$ of respondents were Ethiopian Orthodox Christianity and Islam. The survey result also shows that three ethnic groups exist in the study regionOromo, Amhara and Tigray. Among those ethnic groups, 72\% Oromo, 19.2\% Amhara, and 8.8\% Tigray were taken as sample respondents, respectively (Table 4).

Concerning household family size, Table 5 shows that almost half $(49.6 \%)$ of the total respondents have a household size of 6-10 members. About $31.2 \%$ have 3-5 members. The remaining $15.2 \%$ and $4.0 \%$ have less than 2 and above 11 members. Generally, the study region is characterized by a relatively large family size as more than three-fourths of respondents have more than 5 members.

Educational status is the other characteristic of the community, which indicates the literacy level of households. The survey result signified that most respondents, which account for 50.4\%, are "able to read and write." Respondents who "can't read and write" accounts for $36.8 \%$ total number of respondents. Specifically, 11.2-1.6\% of respondents attended primary and secondary education, respectively (Table 6). This shows that the educational status of the respondents is relatively low. This could hurt the management of the coffee woodland region because deficiency of knowledge about the contribution of the coffee woodland region in preserving biodiversity. 
The economic structure of respondents

As the survey data revealed, almost all of the respondents have land, either woodland or cropland. Concerning the size of land they own, $26.4 \%$ of respondents have between 1.6-2.0 ha land, and $24.8 \%$ of the respondents have between $0.6-1.0$ ha land. The other $20.0 \%$ of the respondents have between 1.1-1.5 ha of land. The remaining $14.4 \%$ of respondents have less than 0.5 and above 2 ha land, respectively (Table 7). As secondary data from land management of the study Woreda reveals, 6,687 households in the Woreda have land; from this, the number of male landowners is 5,921, and the number of female landowners is 766 . The data also reveals that the average landholding size of households in the study region is 2.32 ha. Concerning livelihood activities, agriculture that includes distinct kinds of crop production, woodland products, and animal production are the primary means of subsistence for the community in the study region.

Table 8 shows the primary livelihood strategy of the sample respondents is woodland and woodland-derived provenance, which accounts for $98.4 \%$ of the total livelihood strategy of the community. Products like wild coffee, honey, charcoal, timbers, and non-timber products are mainly utilized as provenances of livelihood by the neighborhood society. Crop production is the other livelihood strategy of sample respondents, which consists $66.7 \%$ of the sample population. Products like maize, teff, and sorghum are the primary products produced by the community in the study region. In addition, livestock rearing is another livelihood strategy of the community, which consists of $34.1 \%$ of the total livelihood strategy of sample respondents. In the study, the region farmer undertakes animal production activities including (cattle, sheep, goat, and donkey) side by side with farm activities.

\section{Institutions of coffee woodland management}

Institutions that encourage the protection of coffee woodland at various levels in a given society are essential to ensure the sustainable existence of coffee woodland. The different institutions have been formed at a particular time and place to respond to increasing pressure on natural provenances. Forest provenances are more likely to be sustainably utilized if an effective structure of institutional adjustments exists that gives rise to an authority system responsible for wise management of origins at the local level (Zewdie 2009). Both official and informal institutional adjustments exist in the study region and are involved in the coffee woodland management practice. That allowing section explains the existing local institution and their role in coffee woodland provenance management.

\section{Informal institution}

Community-initiated autochthonous institutions are principally based on the local people's autochthonous knowledge and long experience. The local communityinitiated informal institutions found in the Bilo-Nopha community, specifically those adjacent to secured coffee woodland regions. Among customary institutions are currently operating and participating in coffee woodland management activities Iddir, the council of elders, and Jiga and Laffee, in the study region is identified.

Table 4. Frequency and percentage distribution of respondents based on their demographic characteristics

\begin{tabular}{lccc}
\hline $\begin{array}{l}\text { Socio-demographic } \\
\text { characteristics }\end{array}$ & Frequency & Percent & $\begin{array}{c}\text { Cumulative } \\
\text { percent }\end{array}$ \\
\hline Sex of respondents & 118 & 94.4 & 94.4 \\
Male Female & 7 & 5.6 & 100.0 \\
Total & 125 & 100.0 & \\
Respondent age & 33 & 26.4 & 26.4 \\
$20-30$ & 21 & 16.8 & 43.2 \\
$31-40$ & 47 & 37.6 & 80.8 \\
$41-50$ & 19 & 15.2 & 96.0 \\
51-60 & 5 & 4.00 & 100.0 \\
Above 60 Total & 125 & 100.0 & \\
Religious affiliation & & & \\
Orthodox & 40 & 32.0 & 32.0 \\
Muslim & 28 & 22.4 & 54.4 \\
Protestant & 57 & 45.6 & 100.0 \\
Total & 125 & 100.0 & \\
Ethnic group & & & \\
Oromo & 89 & 72.0 & 68.0 \\
Amhara & 24 & 19.2 & 87.2 \\
Tigray & 12 & 8.8 & 100.0 \\
Total & 125 & 100.0 & \\
\hline
\end{tabular}

Table 5. Frequency and percentage distribution of respondents by their household size

\begin{tabular}{lccc}
\hline Household size & Frequency & Percent & $\begin{array}{c}\text { Cumulative } \\
\text { percent }\end{array}$ \\
\hline Less than 2 & 19 & 15.2 & 15.2 \\
3-5 & 39 & 31.2 & 46.4 \\
6-10 & 62 & 49.6 & 96.0 \\
11 and above & 5 & 4.0 & 100.0 \\
Total & 125 & 100.0 & \\
\hline
\end{tabular}

Table 6. Frequency and percentage distribution of respondents by their level of education

\begin{tabular}{lccc}
\hline $\begin{array}{l}\text { Educational status of } \\
\text { household head }\end{array}$ & Frequency & Percent & $\begin{array}{c}\text { Cumulative } \\
\text { percent }\end{array}$ \\
\hline I can't read and write & 46 & 36.8 & 36.8 \\
Able to read and write & 63 & 50.4 & 87.2 \\
Primary education & 14 & 11.2 & 98.4 \\
Secondary education & 2 & 1.6 & 100.0 \\
Total & 125 & 100.0 & \\
\hline
\end{tabular}

Table 7. Frequency and percentage distribution of respondents by their landholding size

\begin{tabular}{lccc}
\hline $\begin{array}{l}\text { Landholding size of } \\
\text { respondents }\end{array}$ & Frequency Percent & $\begin{array}{c}\text { Cumulative } \\
\text { percent }\end{array}$ \\
\hline Less than 0.5ha & 18 & 14.4 & 14.4 \\
Between 0.6-1.0ha & 31 & 24.8 & 39.2 \\
Between 1.1-1.5ha & 25 & 20.0 & 59.2 \\
Between 1.6-2.0ha & 33 & 26.4 & 85.6 \\
Above 2.00ha & 18 & 14.4 & 100.0 \\
Total & 125 & 100.0 & \\
\hline
\end{tabular}


Table 8. Frequency and percentage distribution of respondents by their livelihood strategies

\begin{tabular}{lccc}
\hline $\begin{array}{l}\text { Livelihood strategy of } \\
\text { Household }\end{array}$ & \multicolumn{2}{c}{ Frequency Percent } & $\begin{array}{c}\text { Percent of } \\
\text { cases }\end{array}$ \\
\hline Depend on woodland & 121 & $49.4 \%$ & $98.4 \%$ \\
crop production & 82 & $33.5 \%$ & $66.7 \%$ \\
Livestock rearing & 42 & $17.1 \%$ & $34.1 \%$ \\
Total & 245 & $100.0 \%$ & $199.2 \%$ \\
\hline
\end{tabular}

Note: Total is greater than the sample because it is multiple responses

\section{Iddir}

Iddir is a voluntary association that plays a crucial role in administrating coffee woodland in the study regions. As Stellmacher and Mollinga (2009) signified, iddir is an Ethiopian phenomenon. It can be found all over the country and even among Ethiopian communities abroad, across all social classes, ethnicities, and religions. In the specific study region, family is indicated by the head of this association's household. The member of the iddir association held per week and pay for membership contributions to the iddir treasures. They also meet occasionally to nominate a member of iddir committee, which rules the activities of $i d d i r$ association. It also plays a crucial role in managing woodland provenance in the study regions. As in-depth interview result with neighborhood society elders signified, the member of $i d d i r$ social association have regulations that guide their behavior toward the utilization and management of coffee woodland. There is a regulation that punishes those who illegally utilize the secured coffee woodland regions; membership is punished in cash or imprisonment depending on their level of accusation. Some regulations obliged local communities to participate in collective action activities like protection or group meeting. In Nopha village, if the member of $i d d i r$ groups does not participate in collective action activities of woodland management and group meeting, they punish $10 \mathrm{birr}$ and double if they repeat it.

\section{Jiga and laffe}

Jiga and laffe are self-help groups that focus on providing labor, financial and other support to the people exposed to distinct forms of hardship. As neighborhood society elders told the researcher, Jiga is an activity that is performed when the household loses one of its family members whereas, laffe is an activity performed when the household of a given community lost its relatives. The main difference between jiga and laffe is that the former one is morning work from 8-12 clock and later one is night work from 2-5, besides, the member of jiga group is large in number than the member of laffe groups. In the management of coffee woodland region, the role of jiga and laffe are indirect. As Woreda agricultural and woodland preservation office key informants stated, the member of jiga and laffe workgroups utilized as a forum for official discussion between the local communities and government agents regarding the utilization and management of coffee woodland in secured regions.
Through these workgroups awareness creation programs about the biosphere reserve regions and penalties of encroaching the woodland regions are given to the local communities. Their participants do not arrange this working system spontaneously; rather, they have fixed groups and regulations that distinguish members from nonmembers. Jiga and laffe working group's arrangement has regulations that state what, when, and how to manage coffee woodland to protect from damages resulting from illicit user and grazing.

\section{Council of elders}

Council of elders is a group of elders selected by neighborhood society and involved in various social activities such as conflict resolution and decision making in serious societal issues. According to information of elderly key informants, one of such councils of elders in the study region is "Gummaa Abotti Gadda," which plays several roles in the life of neighborhood society. Among others, some of the roles that the council of elders performs are maintaining the culture of the neighborhood society, giving a decision regarding distinct issues, resolving conflict between individuals, and giving awareness creation about securing woodland provenance to the local communities are some of the primary roles of council of elders in the study region. Sera kakal regulation of swear is one of the mechanisms utilized to investigate repeatedly committed crimes through a group of councils of elders. Different kinds of crime, including distraction or illicit utilization of woodland provenances, lead to kaka by the council of elders. The community of the study region has developed a respect for their customary regulations. Fearing kaka, curse, and social sanction would help them forbid the community members from cutting trees in secured regions. The council of elders is fixed and permanent; they also have a high link with the local government administration and work with each other to manage coffee woodland regions.

Generally, customary institutions' role in managing woodland provenance is decreased from time to time in the study region. As elderly key informants signified, the role of customary institutions in the management of coffee woodland is now decreased due to government involvement through its official institutional structures.

The result of FGD discussant group also signified that the organization neighborhood society in distinct state initiated institutions decrease the influence of informal institutions that the neighborhood society perpetuated for a long time.

\section{Formal institution}

There are official institutions related to the utilization and management of coffee woodland. As information obtained from Woreda management and agricultural office indicates, distinct government and non-governmental institutions are involved in administrating the coffee woodland regions. Bilo-Nopha Woreda Management (BNWA), Agriculture and Forest Preservation Office (AFCO), Illubabor Forest Provenance and Wild Animal Enterprise (IFRWAE), Development Agent (DA), and 
NGOs' like Sustainable Land Management (SLM), Ethiopian Coffee Forest Forum (ECFF), People Health and Environment (PHE) and Ethio wet-land are all official stakeholders who operate at the local level in the management coffee woodland regions.

The structure of Bilo-Nopha Woreda Management (BNWA) is arranged hierarchically through top-down control and bottom-up flow of information. As the Woreda communication offices report signified, the hierarchical structure is based on the geographical location of the regions.

The Woreda management is the official local government agency responsible for coordinating the activities of distinct stakeholders who took part in coffee woodland provenance management. Providing administrative, logistics, and giving solutions to the difficulty that is above the capacity of Kebele administrative is the main responsibility of Woreda management.

Kebele management is the other local institution that deals with the daily activities of the rural residents. Under this structure, three zones incorporate 3 up to 7 gares under them. In its role of woodland provenance management, the Kebele management usually imposes penalties on those violating woodland utilization regulations. The lower hierarchical structure reports the illicit utilization of coffee woodland to the kebele management, and then it is up to them to bring the accused people into justice. The Kebele management also has the power to control or allow neighborhood society to utilize products from the coffee woodland region.

Zone, gare, and shane are lower hierarchical structures in which the neighborhood society is arranged to perform distinct management and preservation activities of woodland provenances. Zone is where distinct gares are arranged and talked over on various issues like agricultural and woodland provenance managements. The main role of zone is giving solutions or transferring the subject reported by gare to discussion groups. Gare is the platform for providing possible solutions to the lower disagreement at the shane level. It controls and manage the daily activities of shane groups and gives simple decision like the encroachment of cattle in the secured regions of difficulty over commonly utilized provenances at shane level. Shane is the lowest structural in which farmers are arranged into 1 to 5 cells based on their neighborhood; here, farmers have responsibilities to manage coffee woodland region through controlling each other activities and reporting the illicit utilization of secured woodland by their group members.

According to Woreda agricultural and woodland preservation office director stated, in the management of woodland provenance, the hierarchy shows that, if someone encroaches the secured coffee woodland region at shane level, a member reports to gare group discussion and the gare group transfers it to the zone if it is beyond their capacity to handle it, then the zone tries to give a possible solution or report it to the upper bodies or kebele.

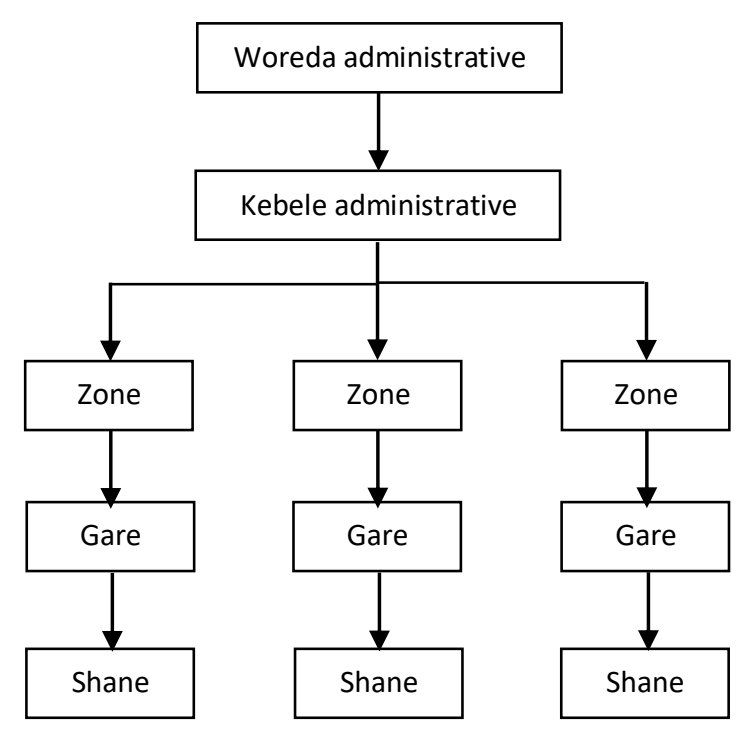

Figure 5. The Hierarchical Structure of Bilo-Nopha Woreda Management

Agriculture and woodland preservation office (AFCO) is the other official institutional adjustment involved in coffee woodland provenances management activities. They work in transitional zone region of the woodland, but also took part in activities like "cut and care" system (the principle that local communities should undertake regeneration activities if they want to utilize trees for distinct construction and home purpose), fire management system (wildfire of woodland for beekeeping), awareness creation service to neighborhood society and plantation of trees and coffee in biosphere reserve regions.

Illu Abba Bora Zone woodland provenance and wild animal enterprise are also involved in coffee woodland management and preservation activities in the study regions. The enterprise has five districts in the five selected biosphere regions and works in all Woredas that coffees woodland were adjacent to the community. The primary activities of this enterprise are organizing and controlling the activities of all members of district workers regarding the management of secured coffee woodland regions, demarcation of woodland boundaries at distinct management regions. As the enterprise manager stated, the enterprise is a self-help organization and not supported by government. It depends on self-generated income by conducting distinct activities like planting of distinct woodland products and selling them to the farmers. They raise the subject of human provenance as one of the big difficulties in effective management of coffee woodland in the biospheres' reserve regions. As key informants from agriculture and woodland preservation office indicate, the enterprise only stand for its own benefit than conserving the woodland region, it took part in few management activities like demarcation of distinct management zone in the years interval merely by marking red line on trees, otherwise, they give more attention to their own income generation activities. 
At the Kebele level Development Agents (DA's) are responsible for planning and implementing distinct activities through the structure of official institution. Among the activities they are undertaking development of team-based afforestation, crop production, and preservation of coffee woodland and carrying out control of soil preservation activities are the primary ones. Development teams are important to manage coffee woodland provenances at local level; they work together with the neighborhood society and undertake awareness creation activities at FTC regarding the significance of woodland provenance in secured regions.

Furthermore, distinct non-governmental organizations (NGO's) like SLM, ECFF, PHE, and Ethio- wetlands are also other stakeholders that are taken part in the management activities of coffee woodland. Almost all of them are involved in activities like the Participatory Woodland Management (PFM), provision of equipment and material, awareness creation service about biosphere reserve regions. Some of the NGO's have an advisory board in the four Kebele which secured coffee woodland are adjacent. The advisory board has an office at local level to talk over on subject of woodland provenance management and difficulty associated with woodland management with local communities. As the Woreda administrator stated to enhance the livelihood of neighborhood society in their own garden coffee region without disturbing the secured woodland, the role of distinct NGO's is high. For example, ECFF provides portable solar machines that decrease neighborhood society dependency on woodland provenances.

\section{Rules affecting community participation to manage coffee woodland}

In the study region even though the degree of participation differs from individual to individual, all of the neighborhood society members have taken part in distinct kinds of management activities to secure the coffee woodland region. Among the management activities performed by local communities to secure the coffee woodland region planting distinct kinds of trees, regeneration activities, group meetings regarding the protection of coffee forest area, and collective action activities like group work are the primary ones. As elderly key informants signified, after coffee woodland region come under the control of state as a national woodland priority region, participation of neighborhood society in the management activities are decreased. The regulation commenced to rule the woodland was cause for a number of household's eviction from their coffee plots on which their livelihood was dependent for many years. Demarcation regulations and ownership rights are the primary factors affecting participation of neighborhood society in coffee woodland management activities. Thus, in the following sub-section, this demarcation and regulations would be discussed in detail.

\section{Demarcation regulation and participation in coffee woodland management}

In the study region, the current demarcation regulations utilized to rule the coffee woodland region are not respected by most of the sampled respondents. Majority of the respondents $73.6 \%$ perceived demarcation regulation as not fair and the other $23.2 \%$ of the respondents perceive the demarcation regulation as fair. The remaining $3.2 \%$ of respondents have observed the demarcation regulation as completely fair. Generally, the results obtained from household survey signified that the current demarcation regulation of coffee woodland is not fair for most of sample respondents.

Moreover, various studies also signified that the impact of coffee woodland demarcation on the livelihood of the neighborhood society is very huge and multi-dimensional. As Zewdie (2009) study signified, demarcation regulations have no advantage for the adjacent community; all it can bring is poverty resulting from the exclusion of community from accessing woodland products mainly wild coffee.

Similarly, in-depth interview results with neighborhood society elders and FGD discussant group revealed that demarcation of woodland provenance has brought impacts on decreased role of neighborhood society regarding the utilization and management right of coffee woodland in biosphere reserve region (core and buffer) zone. As they stated, there are some activities which the community is allowed to do but some others are forbidden and restricted by law.

As informant pointed out the core, zone was a securely secured site for conserving biological diversity by restricting access. In this management zone, many activities are prohibited, including expansion of agricultural land, management of wild coffee, inhabitancy, livestock grazing, timber extraction and collection of dead trees, wild honey harvesting, hunting, and grazing. As the biosphere management guideline shows, only four activities are allowed in the core zone region, i.e., enrichment of plants using autochthonous species, establishment of research plots, ecotourism and education and training center. Although the guideline says this, key informants at Woreda agricultural and woodland preservation office director show, local communities can also utilize distinct spices that do not exist in the buffer zone region, but they are not allowed to cut and carry.

The elderly key informants also add up that, buffer zone is surrounded or contiguous to the core zone. This region acts as a buffer for the core zone and accommodates more human activities. In buffer zone management more than ten activities are prohibited, including inhabitancy, introduction of coffee varieties, planting exotic trees, timber harvesting and hunting of wild animals are the primary ones. In this management zone activities like small-scale agricultural activities, (without expansion of the existing farmland), coffee woodland management (without expansion of woodland land), traditional honey production, and other few activities are allowed.

Preventing neighborhood societies from accessing core zone regions and limiting their utilization right to the buffer zone are intended to decrease pressure on woodland. The goal of current demarcation regulation is to preserve the remaining biodiversity in the coffee woodland region. As key informant interview with district manager of biosphere reserve shows, distinct activities are performed to 
preserve woodland and its inhabited bio-diversity without affecting the livelihood of local communities.

Generally, demarcation regulation of coffee woodland set up by government to preserve primary coffee woodland in distinct parts of the country is one of the regulations that operated as disincentive for neighborhood society to take part in coffee woodland management activities in the study region.

\section{Local community participation in decision-making process}

Empowering local citizens and community organizations in decision-making processes, not only increases efficiency but also provides a real possibility to individuals or groups to transform their choices into desired actions and outcomes, FAO (2010). In the study region, the participation of neighborhood society in any kind of decision-making process is very low, and from the total respondents only few of them had a chance to take part in the decision-making activities at local level and most of them are not participates in any decision-making process regarding the management of coffee woodland at any level.

Table 9 signified that $87.2 \%$ of respondents are not taken part in decision-making process but only $12.8 \%$ of respondents have a chance to take part in decision making process at local level. This implies that majority of the respondents are neither the initiator nor the primary factor in making decision over any events affecting their lives.

Likewise, in-depth interview results with neighborhood society elders signified, government first demarcate the woodland without any prior participation and awareness creation among the local communities. However, only a few members of the communities were got the chance to take part in discussion and decision-making process. Indeed, the first target of the policy was saving the woodland from denudation and then after, turning in to neighborhood society participation and giving awareness creation about the regulation that rule the coffee forest regions. This "prior action and late participation" principle of government generate confusion in the local communities initially when the regulation was applied.

FGD discussant group also signified that the regulation that currently governs the coffee woodland is directly imposed by the government bodies without any prior participation of the community (Table 10). This regulation is discouraging the participation of the community in coffee woodland management through imposing restrictions over the utilization right of distinct woodland products, prohibition of entering the core zone and conducting distinct management activities; prohibition of selective utilization of trees for timber and their own household consumption; limited access of woodland provenance in the buffer zone and prohibition of collecting fuelwood from both core and buffer zone are some of the regulation that imposed on the neighborhood society without any intense participation of them in decision-making process.

The absence of community participation in decisionmaking process initially when the regulation commenced was another factor that operates as disincentive for local communities to take part in the management activities of coffee woodland at biosphere reserve regions.

\section{Ownership right and participation in coffee woodland management}

The respondents were asked whether ownership right of coffee woodland at the bio-sphere region is secure or not. The following frequency table is utilized to indicate the ownership right of respondents in secured coffee woodland region.

Table 11 shows that $88.8 \%$ of respondents answered the ownership right of coffee woodland in secured region as insecure and the remaining $11.2 \%$ of them, on the other hand, answered the ownership right of coffee woodland in secured region as secure. The survey results signified that majority of the respondents have insecure ownership right over their coffee woodland provenances and this, in turn, affects their participation in the management activities.

Yeraswork (2000) clearly stated the significance of secure tenure system in the management of land and landrelated natural provenance. He argued that secure tenure system plays a key role in administrating natural provenances while insecure tenure system is detrimental to the adoption of preservation practices by local communities. Interview result with FGD discussant group also signified that, in the secured region, ownership rights of the local communities are not secure; they do not have a certificate for their buffer zone region (semi-woodland coffee) plots up to now and the bad demarcation experiences they have encountered in the past decrease their participation to manage coffee woodland.

Table 9. Frequency and percentage distribution of respondents based on their perception regarding the current demarcation regulation of coffee forests

\begin{tabular}{lccc}
\hline $\begin{array}{l}\text { Demarcation } \\
\text { regulation }\end{array}$ & Freq. & Percent & $\begin{array}{c}\text { Cumulative } \\
\text { percent }\end{array}$ \\
\hline Completely fair & 4 & 3.2 & 3.2 \\
Fair & 29 & 23.2 & 26.4 \\
Not fair & 92 & 73.6 & 100.0 \\
Total & 125 & 100.0 & \\
\hline
\end{tabular}

Table 10. Frequency and percentage distribution of households based on their participation in decision-making process

\begin{tabular}{lccc}
\hline $\begin{array}{l}\text { Participation in decision- } \\
\text { making process }\end{array}$ & Freq. & Percent & $\begin{array}{c}\text { Cumulative } \\
\text { percent }\end{array}$ \\
\hline No & 109 & 87.2 & 87.2 \\
Yes & 16 & 12.8 & 100.0 \\
Total & 125 & 100.0 & \\
\hline
\end{tabular}

Table 11. Frequency and percentage distribution of respondents regarding their own security

\begin{tabular}{lccc}
\hline Ownership right & Freq. & Percent & $\begin{array}{c}\text { Cumulative } \\
\text { percent }\end{array}$ \\
\hline Secure & 14 & 11.2 & 11.2 \\
Insecure & 111 & 88.8 & 100.0 \\
Total & 125 & 100.0 & \\
\hline
\end{tabular}


As it was mentioned above in the study region the use and management right of woodland provenance in distinct management zone is not similar. In this regard, in the core zone region of coffee woodland, local communities have limited operational level (access and withdrawal) right, i.e., they have the right to enter into the coffee woodland region and harvest only spices without any management activities. Any other activities like wild coffee harvesting, management, beekeeping, timber extraction, etc. are strictly forbidden. In the core zone, neighborhood society has no right over collective-choice level (management, exclusion, and alienation) right at all.

On the contrary, the neighborhood society has relatively both full and limited operational levels (access and withdrawal) right in the buffer zone. Products like wild coffee, traditional honey production, and distinct spices are accessed and removed by the farmers, but some products like timber harvesting, animal fodder, modern beekeeping, and fuel woods are not allowed to be accessed and withdrawn. In this management zone neighborhood society also has some collective-choice level (management and exclusion) right over products like semi-woodland coffee and honey but they do not have alienation right at all.

The above interview result revealed that neighborhood society has lost its ownership right in secured coffee woodland region and their participation in management activities are decreased as compared to before demarcation time in which they have secure ownership right. The ownership right of coffee woodland in biosphere region is the other regulation that operates as disincentive for the local communities to take part in the management of secured coffee woodland region.

\section{Attributes of the coffee woodland user community \\ Cohesiveness, heterogeneity and group size}

Community attributes have made crucial contributions to the enforcement and maintenance of the regulations constituting the management of the prevalent property forests. These community traits are the cohesiveness of communities (engendered by history/myth as to the prevalent origin, the existence of venerated community symbols, and fairly small size, homogeneity of communities, in terms of occupation and wealth) insulation from external forces such as commercial interests (Yeraswork 2001).

Cohesiveness is one important attribute of the community that positively influence the management of coffee woodland in the study region. In Iluu Abba Bora Oromo's consanguine and affinal kinship relations are widely observed. They trace consanguine kinship groups through matrilineal family that is prevalent among the Oromo people (Zewdie 2009). As elderly key informants signified, decades ago neighborhood society of Bilo-Nopha region was highly cohesive due to their prevalent cultural beliefs, norms, and values. They have a culture of prevalent life and their attachment was very high. In the past time, Oromo people had their own traditional beliefs waqefanna. It is belief in one God which is the creator of the whole universe and encompasses woodland ritual and sacred forests. At that time the utilization over coffee woodland region depended on the ancestral background which was known as jahan noonnoo. Jahan noonnoos is kinship system among Illu Abba Bora Oromo which discussed a rightful claim to share of the woodland from elders controlling the allocation. Hence, people who could have traced their descent from the ancestral background utilized and administrated the coffee woodland region and nonmembers were excluded from the utilization right. Through using their prevalent ancestral background, neighborhood society of Bilo-Nopha village maintain their coffee woodland for the past many years.

As literature signified, following the agrarian reform of 1975 the role of customary institution in general and the role of kinship, in particular, cease to exist and were substituted by peasant association and distinct committees established to preserve forest resources throughout the country. Afterward, local communities are also ethnically heterogeneous resulting from their origins in Tigray, Wollo, and Gonder through government-initiated inhabitancy programs.

As elderly key informants signified, following the abolishment of autochthonous institutions and arrivals of re-settlers from other parts of the country there was a difficulty of coffee woodland management in the study region. The competition over woodland products and agricultural land expansion was become high, where the woodland was accessed openly due to the devaluing of customary regulations. Locals were competing to hold the woodland for coffee plantation and landless individuals competed to hold the woodland either for farmland or coffee plantation.

The study region community is also known for its heterogeneity, in terms of occupation, belief system, and other characters. As the survey result signified, most of the communities in the study region depend on woodland and woodland-derived provenance, crop production, and cattle raising as their means of livelihood strategies, they also belong to distinct religious affiliation and ethnic groups.

In the same way, respondents were asked whether the heterogeneity of the community in terms of occupation and ethnicity has an impact on their participation in coffee woodland management activities or not. Accordingly, $83.2 \%$ of respondents answered heterogeneity of the community has no impact on their participation in coffee woodland management but only $16.8 \%$ of respondents responded that heterogeneity has impact on their participation in coffee woodland management (Table 12).

Table 12. Frequency and percentage distribution of respondents in terms of their perception regarding the impact of heterogeneity in coffee woodland management

\begin{tabular}{lccc}
\hline $\begin{array}{l}\text { Heterogeneity of the } \\
\text { community }\end{array}$ & Freq. & Percent & $\begin{array}{c}\text { Cumulative } \\
\text { percent }\end{array}$ \\
\hline No & 104 & 83.2 & 83.2 \\
Yes & 21 & 16.8 & 100.0 \\
Total & 125 & 100.0 & \\
\hline
\end{tabular}


The household survey result implies majority of the respondents perceive that heterogeneity of the community has no impact on their participation in coffee woodland management activities. In fact, it is signified in many literature that, the longtime attachment of woodland provenance users with the woodland concerned, which is very much specified by the 'rootedness' of a community. In this regard, most of the local Oromo population living in their home for many years have high affiliation with the woodland and they have their own norm, culture, and value towards woodland utilization and management than the resettlers. In this regard study by Stellmacher, (2006) also revealed that attributes of the community especially heterogeneity and group size have a great impact in woodland provenance management.

Conversely, the result obtained from in-depth interviews with elderly key informants and FGD discussant group signified, heterogeneity of the community has no impact on the management of coffee woodland. Even though, the neighborhood society consists of distinct ethnic groups especially after the 1980 resettlement program of government both locals and re-settlers have prevalent interest to take part in management of coffee woodland region. The re-settlers to the region simply learn and accept the regulations of the established group and their cultural difference on the other front do not affect their participation in administrating coffee woodland.

The FGD discussant group also signified that before demarcation there is no effective regulation that rules the behavior of local woodland user community, and there was conflict even between the locals over economic interest, but after the coffee woodland region becomes under the custody of government, there are rules that provide a structure to guide which person has which specific right to utilize which woodland provenance to what extent, in which way goods and services are to be used, as well as preservation measures that are to be accomplished. Therefore, there is no disagreement between locals and re-settlers over the utilization and management of coffee woodland regions.

Group size of the local woodland user community is another factor affecting the management of coffee woodland. The study region woodland user community is large in size; the total number of coffee woodland users is 2,670 people living in 1,142 households from the three selected sites of study in Woreda.

As elderly key informants signified, high group size impede the coffee woodland through increasing pressure on woodland provenances and creating conflict of interest and illicit encroachment over the coffee woodland user. Moreover, Ostrom (1999) study states three negative impacts of large group size. First, cost for devising institutions increases with larger groups of appropriators. Second, larger groups enhance ethnic, cultural, and linguistic diversity, hence decreasing homogeneity and thereby complicating shared understanding about provenances and their management. Third, larger appropriator groups have more heterogeneous concerns, perceptions, and assets.

\section{Attribute of the coffee woodland provenances Topography, distance, size, and boundaries of the coffee woodland area}

The woodland of southwest highland of Ethiopia is predominantly of the broad-leafed evergreen type. In the higher regions, above 2,400 $\mathrm{m}$ asl, bamboo (Arundinaria alpine) is found, while in the lower altitudes below $1200 \mathrm{~m}$ asl the high forest grade into lowland forest and then woodland savannas. The specific study regions of BiloNopha Woreda have existed in the south-western part of the country and topographically it is not suitable for any agricultural activities and inhabitancy purposes. It is a mountainous land and difficult to conduct any kinds of activities in this region. The peculiar characteristics of the coffee woodland land are one of the main reasons that neighborhood societies maintain the woodland land for many years.

The other attribute of woodland provenance affecting the management of woodland products is distance from the woodland regions. Respondents were asked how much in hour their homes are far from coffee woodland region and the following frequency table was utilized to indicate the distance of woodland from the home of respondents.

Table 13 depicts that $28 \%$, of respondents, answered that the distance between their home and coffee woodland region is approximately far from $30 \mathrm{~min}-1 \mathrm{hr}$ and the other $20.8 \%$ respondents answered that the distance between their home and coffee woodland region is approximately far from $1 \mathrm{hr}-1.30 \mathrm{hr}$ and $1.30-2.00 \mathrm{hr}$ respectively. The remaining $19.2 \%$ and $11.2 \%$ of respondents were answered in less than $30 \mathrm{~min}$ and above $2.00 \mathrm{hr}$ that their home is far from the coffee woodland regions. The above household survey result depicted, majority of the respondents are far in distance up to $2.00 \mathrm{hr}$ from the coffee woodland region and their participation is less in the management activities. As the further coffee woodland region is far from the home of neighborhood society, the lower participation of neighborhood society in coffee woodland management.

Similarly, a study conducted by Gunatilake, (1998) signified that the distance from the woodland is also considered as a contributing factor for coffee woodland management activities. Proximity to the woodland has an effect on natural provenance management. Those who are close to the woodland will rely more on natural provenance than those are far from it. This means if people travel small distances to collect natural provenance products, there is a high tendency of visiting on daily or weekly basis.

Table 13. Frequency and percentage distribution of respondents in terms of their distance from coffee woodland region

\begin{tabular}{lccc}
\hline Distance from woodland & Freq. & Percent & $\begin{array}{c}\text { Cumulative } \\
\text { percent }\end{array}$ \\
\hline Less than $30 \mathrm{~min}$ & 24 & 19.2 & 19.2 \\
$30 \mathrm{~min}-1 \mathrm{hr}$ & 35 & 28.0 & 47.2 \\
$1.00 \mathrm{hr}-1.30 \mathrm{hr}$ & 26 & 20.8 & 68.0 \\
$1.30 \mathrm{hr}-2.00 \mathrm{hr}$ & 26 & 20.8 & 88.8 \\
Above $2.00 \mathrm{hr}$ & 14 & 11.2 & 100.0 \\
Total & 125 & 100.0 & \\
\hline
\end{tabular}


Table 14. Frequency and percentage distribution of respondents in terms of their perception about multiple utilization of coffee woodland

\begin{tabular}{lccc}
\hline $\begin{array}{l}\text { Goods and services from } \\
\text { woodland products }\end{array}$ & Freq. & Percent & $\begin{array}{c}\text { Percent of } \\
\text { case }\end{array}$ \\
\hline Cash income earning & 120 & $36.8 \%$ & $96.0 \%$ \\
Subsistence utilization & 81 & $24.8 \%$ & $64.8 \%$ \\
Biodiversity preservation & 71 & $21.8 \%$ & $56.8 \%$ \\
Soil erosion and water preservation & 54 & $16.6 \%$ & $43.2 \%$ \\
Total & 326 & $100.0 \%$ & $260.8 \%$ \\
\hline
\end{tabular}

Note: Total is greater than sample because it is multiple response answers

In the same way, to survey, the in-depth interview result obtained from selected neighborhood society elders and FGD discussant group also confirm that the core zone region is very far from the home of neighborhood society and it takes up to seven hours to reach into it. Buffer zone relatively near to the home of neighborhood society, and they took part more in this management zone than core zone region which far from their home.

Concerning size and boundaries, the coffee woodland region is very difficult for effective control. As in-depth interview results with selected neighborhood society elders signified, the size of the coffee woodland region is vast, and there are no clear boundaries for effective management. As elderly informants stated, the largeness of the coffee woodland regions by itself generates difficulties of effective control and management activities. Besides the largeness, the coffee woodland there is also no clear boundaries that exclude non-member to control illicit users. People from Suphe and Alge Woreda come up to Nopha inside of the coffee woodland regions to extract woodlandderived products. There are also no guards to secure and control the coffee woodland regions, because it is beyond the capacity of local management to hire many guards at a time.

As neighborhood society elders told the researcher, even though the coffee woodland region is large in size and there is also no clear boundary to exclude others, before demarcation neighborhood society by itself manage the coffee woodland region sustainably through using their own traditional mechanism without any difficulties. But after demarcation, illicit users have intensified due to government control of the woodland by prohibiting the utilization and management rights of people.

\section{The qualities of the coffee woodland derived provenances}

The other positive attribute that enhances the protection and maintenance of coffee woodland provenances is, its derived goods and services. Natural provenance is endowed with distinct provenance that is a necessity needed by the neighborhood society, these are its quality of being a provenance of abundant woodland products and/or services when humans invest time, labor and/or capital input to extract them from woodland provenances (Stellmacher 2006).

It is the fact that, the coffee woodland in the study region were administrated not only due to its inconvenient physical attribute but also administrated due to distinct goods and services they provide for the local communities, for instance, wild coffee, beekeeping, fuelwood, timber for construction and biodiversity preservation are some of the goods and services that coffee woodland in the study region provided for the communities. Consequently, the neighborhood society members have prevalent interest to manage the coffee woodland region.

Respondents were asked about the significance of coffee woodland based on the goods and services they provide. Accordingly, 96\%, of the respondents perceive the significance of coffee woodland as provenance of cash income. The other $64.8 \%$ and $56.8 \%$ of the respondents were perceiving the significance of coffee woodland as subsistence utilization and preserving biodiversity respectively. A sizable few $43.2 \%$ of the respondents perceive the significance of coffee woodland as securing soil erosion and water preservation respectively (Table 14).

Similarly, the result obtained from in-depth interviews with neighborhood society elders and FGD discussant group also signified that the livelihood of most of the communities depends on woodland and woodland-derived provenances. They utilized woodland and woodlandderived product as a means of their income generation so as to fulfill the basic needs of their family members. Local communities secure and actively took part in the management of coffee woodland region as it has significant contribution to their livelihood strategies. In sum, attribute of woodland land and its derived goods and service operations as incentive and disincentive to manage coffee woodland in the study region.

\section{Challenges of coffee woodland management}

Coffee woodland of southwestern Ethiopia witnesses alarming denudation at annual rate of up to $9 \%$. This is mainly due to the expansion of small holder's agriculture and overutilization of timber and non-timber woodland products driven by poverty, this development does not only promote change of local climate, land degradation, erosion and scarcity of woodland products-all worsening poverty cycle but also leads to the irreversible detriment of woodland bio-diversity and the coffee gene pool (Stellmacher and Mollinga 2009).To decrease denudation and maintain distinct biodiversity in the coffee woodland region, government set up the national forest priority area (NFPA) program that is utilized to preserve woodland in distinct management zone. The regulation that forbids and restricts the utilization of distinct coffee woodland products in secured regions by neighborhood society generates other difficulties in the lives of woodland adjacent communities.

Result from in-depth interviews with neighborhood society members and FGD discussant group signified, deficiency of sense of ownership is one of the primary difficulties affecting the management of coffee woodland after demarcation regulation imposed on neighborhood society to rule the secured regions. Different forms of ownership existed before demarcation including private goods and prevalent property provenance. After demarcation, however, most of the community members have no both operational-level (access and withdrawal) and collective-choice level (management, exclusion, and 
alienation) rights. This makes the utilization and preservation of coffee woodland very difficult. Local community members have been administrating their coffee woodland provenance which was bequeathed from their forefathers through autochthonous provenance management mechanisms for the preceding years and still now claims ownership right. In the preceding years, the buffer zone coffee woodland region was their own individual plot and the core zone region was utilized as a prevalent property provenance. Before the current regulation used to administrate the woodland region, there was through autochthonous institutions like council of elders, and distinct local arranged workgroups that prevalent property provenance was administrated and any kind of illicit utilization over coffee woodland provenances were handled. Due to the 1975 agrarian reform, the role of that autochthonous institution was weakened and substituted by distinct another government official legal structure like peasant association. Now, after the bad demarcation regulations, neighborhood society dispossessed their prerogatives and ownership right both at the core and buffer zone regions.

Similarly, the effects acquired from FGD discussant group also found out that the application of demarcation rule without any intense attendance of the neighborhood society members in choice-making process, decrease their attendance in coffee woodland management activities. As discussants said, after demarcation of coffee woodland location, neighborhood society senses deficiency of the impression of possession even for their semi-woodland plot inside the demarcated regions. This is because they do not possess certificates or green cards that insure their warranty for private lands.

Illicit encroachment is the other dispute affecting the management of coffee woodland in the study site. The illegal utilization of various woodland products like timber logging and cutting trees have accelerated in the preceding few years due to neighborhood societies dispossessed woodland provenance ownership that they utilize and administrated for the preceding few years. As elderly key informants signified, monitoring all parts of the coffee woodland site is very hard, because it includes13.305 ha undisturbed woodland land and there may be also no guards that manipulate the woodland site vicinity. Illicit encroachment of coffee woodland areas in the secured vicinity increases due to the deficiency of effective rule that administrate the woodland areas particularly after it ends up under the possession of government.

On contrary to what the Nopha Woreda administrator stated, that is, there are enhancements in administrating illicit encroachments after demarcation of woodland as a countrywide priority area, but the result received from elderly key informants signified the opposite of what was stated by Woreda administrator. As they signified, presently illegal encroachment could be very high compared to the preceding years whereupon nearby societies administrated their own woodland in line with the guidelines handed of their conventional customs.

Up to now, the neighborhood societies are claiming their possession of the woodland areas, and nonetheless, there are conflictual relationships that exist between neighboring communities and government agents. As the informants stated, confrontation over the de jure ownership of woodland provenance in study site worsens the growth of illicit encroachment, fast denudation, and degradation of woodland area provenance populations.

In distinct cases, inadequacy of adjustment and clearcut area of responsibilities in distinct shape of official institutions are the other dispute of coffee woodland management inside the study areas. As key informant interview with bio-sphere reserve supervisor indicated, there is false impression from distinct stakeholders in comprehending the standard of the rule that administrates coffee woodland at the core and buffers management regions. On one hand, government agents understand that there may be no difference between the core and buffer management area in the impression that both regions are secured and any form of utilization and management activities are strictly prohibited. On the other hand, distinct stakeholders like NGO's realize that there is a distinction in the core and buffer management zone via using UNESCO Man and Biosphere principle. In keeping with the rule, neighborhood community has some utilizations and management right over their buffer zone woodland sites. This false impression creates tremendous confusion on the neighborhood coffee woodland users. While the director of biosphere reserve stated, this year, because of false impression of distinct stakeholders about the rule that administrate coffee woodland site, 5 farmers were arrested in the other block of the coffee woodland area for using forbidden products in buffer management area.

These issues of thought are arising from inadequacy of coordination among dissimilar stakeholders participating in management activities. The coordination of dissimilar stakeholders is poor and less coordinated; all of them operate with no prevalent strategy and goals leading to prevalent ends. There is additionally very little accountability and transparency between dissimilar areas of position facilitating the practical management of coffee woodland. Therefore, inadequacy of well-coordinated relationship between distinctive stakeholders participating in management activities aggravates the issue of coffee woodland provenance management in the study locations.

In conclusion, although distinctive anthropogenesis factors like overpopulation caused by both natural increase and migration, exploitation of timber for economic and house consumption purposes, alteration of woodland land into agricultural and new inhabitancies have threatened the presence of various multifariousness that is found in coffee woodland areas. However, the principles that formulate to resolve the above issue led to the creation of other big issues on the livelihoods of the surrounding people within the study site. Since the rules used by the government are less participatory and are derived from the happening of foreign countries, surrounding society had no probability to take part in the scenario that has an effect on their lives. The unintended and uncoordinated nature of the rule resulted in eviction of surrounding society from their woodland land, insecurity of possession rights, illegitimate 
encroachment over the secured coffee woodland and conflict between the indigenous communities and government agents.

\section{REFERENCES}

Agrawal A. 2007. Forests, Governance, and Sustainability: Common PropertyTheory and its Contributions.International Journal of the Commons 1 (1). DOI: 10.18352/ijc.10.

Andinet D. 2010. Local-level institutions and their influence on forest resource management: the case of Yayo Forest in Iluu Abba Bora Zone, Southwest Ethiopia. [MA thesis]. Department of development studies, Addis Ababa University, Ethiopia.

Amogne A. 2013. Forest resource management systems in Ethiopia: Historical perspective. Intl J Biodiv Conserv 6 (2): 121-131. DOI 10.5897/IJBC2013.0645.

Camic RPM, Yardley L. (Ed.). 2003. Qualitative research in psychology: Expanding perspectives in methodology and design. American Psychological Association, Washington, DC. DOI: 10.1037/10595000 .

Gunatilake HM. 1998. The role of rural development in protecting tropical rainforests: evidence from Sri Lanka. J Environ Manag 53 (3): 273 292. DOI: 10.1006/jema.1998.0201.

Mellese D, Mohammud A. 2005. Legal institutional analysis for sustainable use of forest resource: the case of Sheka forest in southwestern Ethiopia. Proceedings of the 8th Annual Conference of Agricultural Economics Society of Ethiopia, February 24-26, 2005, Addis Ababa.

Ostrom E. 1999. Self-Governance and Forest Resources, CIFOR Occasional Paper No. 20. Center for International Forestry Research (CIFOR), Bogor.

Stellmacher. 2006. Governing Ethiopian Coffee Forests: A Local Level Institutional Analysis in Kaffa and Bale Mountains. [Dissertation]. Department of Political and Cultural Change, University of Bonn, Germany.

Stellmacher T, Mollinga PP. 2009. The institutional sphere of coffee forest management in Ethiopia. Intl J Soc For 1 (1): 43-66.

Tadesse W, Demel T. 2001. 'The Forest coffee ecosystems: ongoing crisis, problems and opportunities for coffee gene conservation and sustainable utilization. Department of Biological Society of Ethiopia, Addis Ababa.

Teklu T. 2006. Coffee forest conservation: local-level institutions influencing the conservation and use of coffee forests in southwestern Ethiopia. [Dissertation]. University of Hohenheim, Germany.

Yeraswork A. 1997. Forest, Animal and People: Surviving through Harmony- AStudy of the Desse'a Forest of Eastern Tigray. Conference on Environment and Development in Ethiopia, June 12$15,1997$.

Zewdie J. 2009. Institutions, incentive and conflict in the Conservation and Use of Coffea arabica. The case of Yayo Forest in Iluu abba Bora Zone, Southwest Ethiopia. [Dissertation]. University of Bonn, Germany. 